\title{
Expression of TIGIT in splenic and circulatory T cells from mice acutely infected with Toxoplasma gondii
}

\author{
Shuai Wang ${ }^{1, a,}$, Haoran $\mathrm{Li}^{1, \mathrm{a}}$, Fuqiang Zhang ${ }^{1}$, Yuankai Jiao ${ }^{2}$, Qing Xie ${ }^{1}$, Zhenchao Zhang ${ }^{1}$, and Xiangrui Li ${ }^{1,3, *}$ \\ ${ }^{1}$ Xinxiang Key Laboratory of Pathogenic Biology, School of Basic Medical Sciences, Xinxiang Medical University, \\ Xinxiang, 453003 Henan, PR China \\ ${ }^{2}$ Second Clinical Medical College, Xinxiang Medical University, Xinxiang, 453003 Henan, PR China \\ ${ }^{3}$ MOE Joint International Research Laboratory of Animal Health and Food Safety, College of Veterinary Medicine, Nanjing Agricultural \\ University, Nanjing, 210095 Jiangsu, PR China
}

Received 29 August 2020, Accepted 4 February 2021, Published online 25 February 2021

\begin{abstract}
The surface protein TIGIT (T cell immunoglobulin and immunoreceptor tyrosine-based inhibitory motif (ITIM) domain) has been characterized as an important regulator of cell-mediated immune responses in various infections. However, TIGIT expression in immune cells of mice infected with Toxoplasma gondii has not been investigated. Here, we detected TIGIT expression and related phenotypes by flow cytometry and real-time PCR in splenic and circulatory $\mathrm{T}$ cells of mice infected with the $T$. gondii $\mathrm{RH}$ strain. We found that the expression of TIGIT on the surface of $\mathrm{CD}^{+} \mathrm{T}$ cells and $\mathrm{CD} 8^{+} \mathrm{T}$ cells from the spleen and peripheral blood mononuclear cells decreased in the early stage, but increased significantly in the late stage of acute $T$. gondii infection in mice. Importantly, TIGIT expression was positively correlated with lesions in the murine spleen. In addition, $T$. gondii-specific TIGIT $^{+} \mathrm{T}_{\mathrm{CM}}$ cells in the spleen were activated and transformed into TIGIT $^{+} \mathrm{T}_{\mathrm{EM}}$ cells. Hematoxylin and eosin staining of spleen sections and real-time PCR showed that the severity of splenic lesions was positively correlated with the $T$. gondii load. This study demonstrates that acute $T$. gondii infection can regulate the expression of TIGIT in T cells and affect immune cell function.
\end{abstract}

Key words: Toxoplasma gondii, T cells, TIGIT, CD226.

Résumé - Expression de TIGIT dans les cellules T spléniques et circulatoires de souris lourdement infectées par Toxoplasma gondii. La protéine de surface TIGIT a été caractérisée comme un régulateur important des réponses immunitaires à médiation cellulaire dans diverses infections. Cependant, l'expression de TIGIT dans les cellules immunitaires de souris infectées par Toxoplasma gondii n'a pas été étudiée. Ici, nous avons détecté l'expression de TIGIT et les phénotypes associés par cytométrie en flux et PCR en temps réel dans les cellules T spléniques et circulatoires de souris infectées par la souche RH de $T$. gondii. Nous avons constaté que l'expression de TIGIT à la surface des cellules T CD4 + et des cellules T CD8 + de la rate et des cellules mononucléées du sang périphérique diminuait au stade précoce, mais augmentait de manière significative au stade avancé de l'infection aiguë à $T$. gondii chez la souris. Surtout, l'expression de TIGIT était positivement corrélée avec les lésions de la rate de la souris. De plus, des cellules TIGIT ${ }^{+} \mathrm{T}_{\mathrm{CM}}$ spécifiques de $T$. gondii dans la rate ont été activées et transformées en cellules $\mathrm{T}_{\mathrm{EM}}$. La coloration à l'hématoxyline et à l'éosine (H\&E) des coupes de rate et la PCR en temps réel ont montré que la gravité des lésions spléniques était positivement corrélée à la charge en $T$. gondii. Cette étude démontre qu'une infection aiguë par T. gondii peut réguler à la hausse l'expression de TIGIT dans les cellules $\mathrm{T}$ et affecter la fonction des cellules immunitaires.

\section{Introduction}

The obligate intracellular parasitic protozoan Toxoplasma gondii ( $T$. gondii) infects most warm-blooded animals and seriously threatens the health of human beings and animals

\footnotetext{
*Corresponding authors: tongbaiws1003@163. com,

lixiangrui@njau.edu.cn

${ }^{a}$ These authors contributed equally to this paper.
}

$[7,20]$. It has been reported that more than one-third of people around the world are infected with $T$. gondii, and its incidence is increasing each year $[9,22]$. The transmission of $T$. gondii in humans may result from ingestion of food or water contaminated with oocysts excreted by infected cats or ingestion of raw or undercooked meat containing tissue cysts. Transplacental or vertical transmission from the mother to the fetus occurs when tachyzoites pass through the placenta during pregnancy, or medical intervention (e.g., blood transfusion or organ 
transplantation) [8]. Toxoplasmosis is often asymptomatic when host immune function is normal. When the immune function of the host is impaired, T. gondii will spread widely within the host via blood circulation and repeatedly invades and proliferates within host cells, resulting in damage to multiple organs and even death of the host [16].

Cell-mediated immune responses play important roles in T. gondii infection $[10,12]$. T cells, NK cells, macrophages, INF- $\gamma$, TNF- $\alpha$ and NO are all key components of this protective immune response, among which $\mathrm{T}$ cells are particularly critical during $T$. gondii infection [10, 17]. A significant feature of the strong immune response of the host to intracellular pathogens is the rapid proliferation of specific $\mathrm{T}$ cells and the secretion of multiple functional cytokines. After $T$. gondii infection, specific $\mathrm{T}$ cells and NK cells proliferate, mediate cytotoxicity and produce many cytokines, such as TNF- $\alpha$ and IFN- $\gamma$, that play critical roles in anti- $T$. gondii infection [19, 23].

Studies have shown that chronic T. gondii infection can cause host $\mathrm{T}$ cell exhaustion. High expression of inhibitory receptors such as PD-1, TIM-3 and TIGIT [T cell immunoglobulin and immunoreceptor tyrosine-based inhibitory motif (ITIM) domain] on the surface of exhausted T cells significantly inhibited the effector function of $\mathrm{T}$ cells [2, 3]. A study found that the proliferative activity of $\mathrm{T}$ cells and their ability to secrete factors were restored in a mouse model of $T$. gondii infection after blocking the PD-1-PDL-1 pathway, and the survival rate of the mice increased to $90 \%$. Therefore, it is necessary to identify other checkpoint receptors that mediate $\mathrm{T}$ cell exhaustion caused by $T$. gondii infection [3].

TIGIT is encoded on human chromosome 16 and is mainly expressed on NK cells, Treg cells and helper T cells [4, 13]. TIGIT binds to the ligands CD155 (PVR) and CD112 (PVRL2, nectin-2). Both ligands are expressed on antigen presenting cells (APCs) and many non-hematopoietic cell types, including tumor cells, and share a signaling network with the costimulatory receptor CD226 (DNAM-1) [5, 6]. The binding affinity of CD226 for these ligands is approximately 10 times weaker than that of TIGIT. TIGIT can inhibit the interaction between CD226 and CD155 in a dose-dependent manner. In addition to ligand competition, TIGIT can also directly bind to cis isomers of CD226 and disrupt its costimulatory function $[11,15]$. Studies have shown that the expression of TIGIT on T cells increased after infection with Echinococcus multilocularis, Plasmodium berghei or Schistosoma japonicum, and was negatively correlated with the immune function of $\mathrm{T}$ cells [14, 24, 25]. Nevertheless, it has not been reported whether TIGIT affects the $\mathrm{T}$ cell immune response during acute $T$. gondii infection.

In the present study, we aimed to investigate the expression of TIGIT on splenic and circulatory lymphocyte populations and related phenotypes of these cells during acute $T$. gondii infection.

\section{Materials and methods \\ Mice and parasites}

The RH strain (type I, virulent strain) of $T$. gondii used in this experiment was preserved by the Department of Human Parasitology, Xinxiang Medical University. Male C57BL/6 mice
(7-8 weeks old) were purchased from Beijing Vital River Experimental Animal Technology Co., Ltd., and maintained in animal facility under specific pathogen-free conditions. All animal experiments were reviewed and approved by the Ethics Committee of Xinxiang Medical University (ref. No. 20170305).

\section{Infection experiments}

C57BL/6 mice were divided into an infection group $(n=75)$ and a control group $(n=75)$. The tachyzoites of the RH strain were obtained from the peritoneal fluid of C57BL/6 mice that had previously been inoculated with the RH strain. Mice in the infection group were injected intraperitoneally with 200 tachyzoites of the RH strain, and the same volume of phosphate buffered saline (PBS) solution was injected into the control group.

\section{Separation and preservation of tissue}

Ten mice in each group were randomly sacrificed at $0,1,3,5$ and 7 days after infection. Anticoagulated blood was collected aseptically from the mouse orbit, and the red blood cells were removed with erythrocyte lytic solution and then frozen at $-80{ }^{\circ} \mathrm{C}$ for future use. The spleens of five mice were removed aseptically, ground with liquid nitrogen and frozen at $-80^{\circ} \mathrm{C}$ for future use. For the other five mice, mouse spleens were removed and immediately fixed in $10 \%$ formalin, and 5 - $\mu$ m-thick spleen sections from each mouse were stained with hematoxylin and eosin (H\&E) and evaluated for histopathological changes.

\section{Preparation of peripheral blood mononuclear cells (PBMCs) and splenic mononuclear cells (SMCs)}

Five mice in each group were randomly sacrificed at $0,1,3$, 5 and 7 days after infection. Peripheral blood mononuclear cell (PBMC) isolation was performed by aseptic orbital acquisition of fresh ethylenediaminetetraacetic acid (EDTA) anticoagulant peripheral blood, which was then diluted with PBS preheated to $37{ }^{\circ} \mathrm{C}$. Then, the anticoagulant was slowly spread on the upper layer of lymphocyte separation solution that was preheated to $37^{\circ} \mathrm{C}$ and centrifuged at $500 \times g$ for $20 \mathrm{~min}$; subsequently, different layers were observed. The middle layer containing lymphocytes was adsorbed and transferred to a $15 \mathrm{~mL}$ centrifuge tube preloaded with $10 \mathrm{~mL}$ of PBS. The sample was centrifuged for $10 \mathrm{~min}$ at $4{ }^{\circ} \mathrm{C}$ and $400 \times g$, and the supernatant was removed. The cell precipitate was resuspended in flow cytometry staining (FACS) buffer (PBS with $2 \%$ FCS), and the cells were counted.

Splenic mononuclear cell (SMC) isolation included aseptic isolation of the mouse spleen. Once removed, the spleen was placed in a Petri dish with a diameter of $6 \mathrm{~cm}$ (preloaded with $200 \mathrm{mesh} / 25.4 \mathrm{~mm}^{2}$ nylon mesh), and $5 \mathrm{~mL}$ of FACS buffer was added. Next, the spleen was cut, and the filter cloth was tightened (the filter cloth was half submerged in PBS). A $20 \mathrm{~mL}$ syringe piston was used to grind the spleen until there were no obvious masses, and the cell suspension was collected 
Table 1. Sequences of the primers used in this study.

\begin{tabular}{|c|c|c|c|}
\hline \multirow{2}{*}{$\begin{array}{l}\text { GenBank accession } \\
\text { XM_002368164.2 }\end{array}$} & \multicolumn{2}{|c|}{ Gene and primer sequence } & \multirow[t]{2}{*}{ Target gene length } \\
\hline & T. gondii SAG1 (TgSAG1) & & \\
\hline & Sense primer & $5^{\prime}$-ATCGCCTGAGAAGCATCACTG-3' & $101 \mathrm{bp}$ \\
\hline & Antisense primer & $5^{\prime}$-CGAAAATGGAAACGTGACTGG-3' & \\
\hline \multirow[t]{3}{*}{ NM_007393.5 } & $\beta$-actin & & \\
\hline & Sense primer & $5^{\prime}$-GATGCAGAAGGAGATTACTG-3' & $91 \mathrm{bp}$ \\
\hline & Antisense primer & $5^{\prime}$-ACCGATCCACACAGAGTA-3' & \\
\hline \multirow[t]{3}{*}{ NM_001146325.1 } & TIGIT & & \\
\hline & Sense primer & 5'-GGCATGTCGCTTCAGTCTTC-3' & 139 bp \\
\hline & Antisense primer & 5'-СТССССТТGTАААТСССАCС--3' & \\
\hline \multirow[t]{3}{*}{ NM_178687.2 } & CD226 & & \\
\hline & Sense primer & 5'-ACCACATGGCTTTCTTGCTC-3' & $112 \mathrm{bp}$ \\
\hline & Antisense primer & $5^{\prime}$-CAGCATGAGAGTTGGACCAG-3' & \\
\hline
\end{tabular}

in a $15 \mathrm{~mL}$ centrifuge tube prefilled with $5 \mathrm{~mL}$ of $37{ }^{\circ} \mathrm{C}$ lymphocyte separation solution. Then, the samples were centrifuged at $500 \times g$ and $25{ }^{\circ} \mathrm{C}$ for $20 \mathrm{~min}$, followed by the same steps described for peripheral blood.

\section{Flow cytometry}

The SMCs and PBMCs were incubated with FcR Blocking Reagent (Miltenyi Biotec, 130-092-575) at $4{ }^{\circ} \mathrm{C}$ for 10 min to block non-specific immunoglobulin binding to Fc receptors, stained with Viobility 405/520 Fixable Dye (Miltenyi Biotec, 130-092-575) at $4{ }^{\circ} \mathrm{C}$ for $30 \mathrm{~min}$, and washed once with FACS buffer. The cells were incubated with specific antibodies or isotype controls, according to the manufacturer's guidelines. The antibodies used were as follows: anti-mouse Abs against CD3E-APC-Vio770, mouse (Miltenyi Biotec, 130-117-676), CD8a-PE-Vio770, mouse (Miltenyi Biotec, 130-102-358), PE/Dazzle 594 anti-mouse CD4 Antibody (BioLegend, 100456), Brilliant Violet $421^{\mathrm{TM}}$ anti-mouse TIGIT (Vstm3) Antibody (BioLegend, 142111), Brilliant Violet 421 ${ }^{\mathrm{TM}}$ Mouse IgG1, א Isotype Ctrl Antibody (BioLegend, 400157), FITC anti-mouse CD226 (DNAM-1) (BioLegend, 128803), FITC Rat IgG2b, $\kappa$ Isotype Ctrl Antibody (BioLegend, 400634), PE anti-mouse/human CD44 (BioLegend, 103007), and Alexa Fluor $^{(} 488$ anti-mouse CD62L Antibody (BioLegend, 104420). All flow cytometry acquisitions were performed using CytoFLEX (Beckman Coulter, Brea, CA, USA) under the same application settings. Flow cytometry data analysis was performed using CytExpert 2.1 software.

\section{Quantitative real-time PCR}

Total RNA was extracted from PBMCs and spleen tissues using TRIzol reagent (Yi Fei Xue Biotechnology, Nanjing, PR China) and then converted to first-strand cDNA using a Script 1st Strand cDNA Synthesis Kit (Yi Fei Xue Biotechnology, Nanjing, PR China), according to the manufacturer's protocol. cDNA was obtained by reverse transcription PCR on a thermal cycler (Eppendorf, Hamburg, Germany). The product was directly used for quantitative real-time PCR (RT-PCR).

As a measure of parasite load, the $T$. gondii tachyzoitespecific gene SAG1 (TgSAG1) was amplified by RT-PCR
[3]. To determine mRNA expression levels of TIGIT and CD226 in the PBMCs and spleens from mice, RT-PCR was performed using ChamQ Universal SYBR qPCR Master Mix (Vazyme Biotech, Nanjing, PR China), and QuantStudio ${ }^{\mathrm{TM}} 5$ (Applied Biosystems, Foster City, CA, USA) was used to analyze the amplification products. The PCR primers used herein are listed in Table 1. The reaction conditions were as follows: initial denaturation at $95^{\circ} \mathrm{C}$ for $30 \mathrm{~s}$, followed by 40 amplification cycles (denaturation at $95{ }^{\circ} \mathrm{C}$ for $10 \mathrm{~s}$, annealing at $60^{\circ} \mathrm{C}$ for $30 \mathrm{~s}$, and extension at $72{ }^{\circ} \mathrm{C}$ for $30 \mathrm{~s}$ ). Values are means from triplicate measurements; specific mRNA expression levels were normalized to the housekeeping gene $\beta$-actin mRNA. The results were calculated using the $2^{-\triangle \triangle \mathrm{Ct}}$ method.

\section{Statistical analysis}

Statistical analysis was performed using SPSS 20 software for Windows (SPSS Inc., Chicago, IL, USA). Student's $t$ test was used to compare the differences between the two groups, and one-way ANOVA was used to compare the differences between multiple groups (one-way ANOVA). The results were considered significantly different when $p<0.05$.

\section{Results \\ Acute $T$. gondii infection specifically regulated the expression of TIGIT on T cells}

Compared with that of the control group, the TIGIT expression of $\mathrm{CD}^{+}$and $\mathrm{CD}^{+} \mathrm{T}$ cells among PBMCs of the infection group was significantly upregulated on the 7 th day post infection (TIGIT ${ }^{+} \mathrm{CD}^{+} \mathrm{T}$ cell: $5.58 \% \pm 1.30 \%$ vs. $72.72 \% \pm 0.64 \%$, $p<0.001$; TIGIT $^{+} \mathrm{CD}^{+} \mathrm{T}$ cells: $13.15 \% \pm 2.32 \%$ vs. $78.72 \% \pm 2.06 \%, p<0.001)$. Similarly, the proportion of TIGIT $^{+} \mathrm{T}$ cells in the spleen of infected mice was much higher than that of the control mice $\left(\right.$ TIGIT $^{+} \mathrm{CD}^{+} \mathrm{T}$ cells: $19.85 \% \pm 0.41 \%$ vs. $59.50 \% \pm 2.5 \%, p<0.001$; TIGIT $^{+} \mathrm{CD}^{+} \mathrm{T}$ cells: $8.07 \% \pm 1.19 \%$ vs. $79.48 \% \pm 3.40 \%, p<0.001)$. During the infection process, TIGIT expression in T cell subsets within PBMCs and spleens from the infection group decreased on the third day post infection; this trend was more obvious in $\mathrm{CD}^{+} \mathrm{T}$ cells, but it only lasted until the fifth day after infection in $\mathrm{CD}^{+} \mathrm{T}$ cells within PBMCs (Fig. 1). 

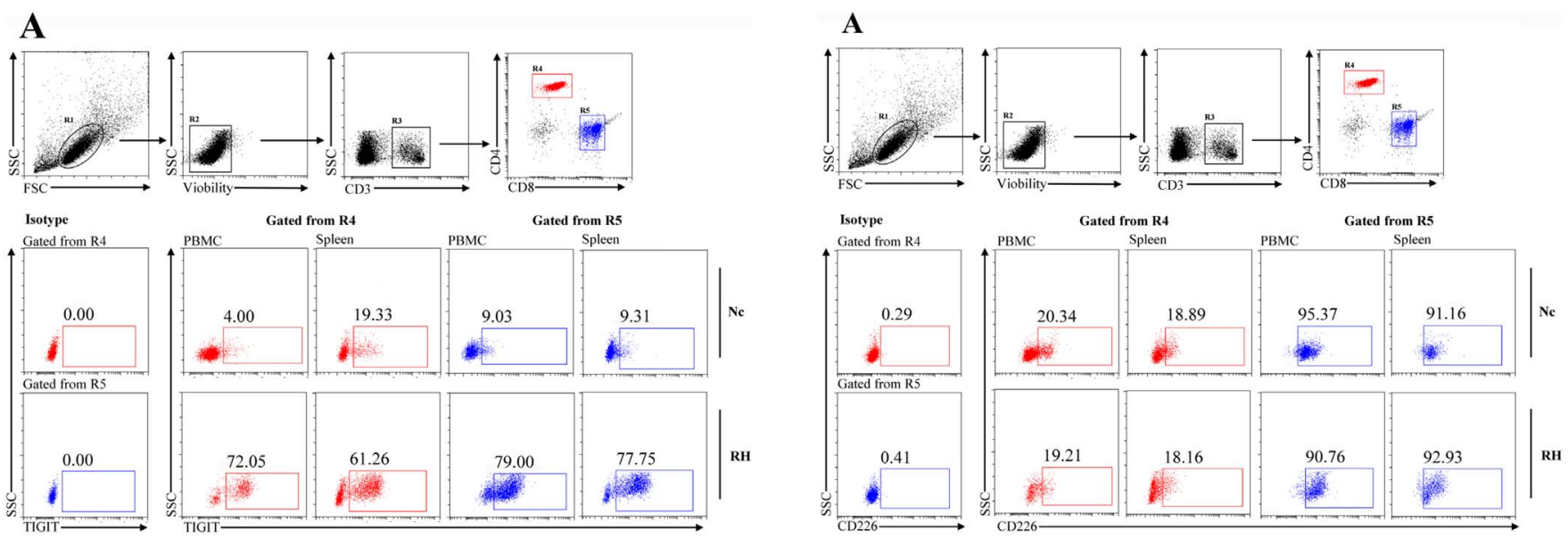
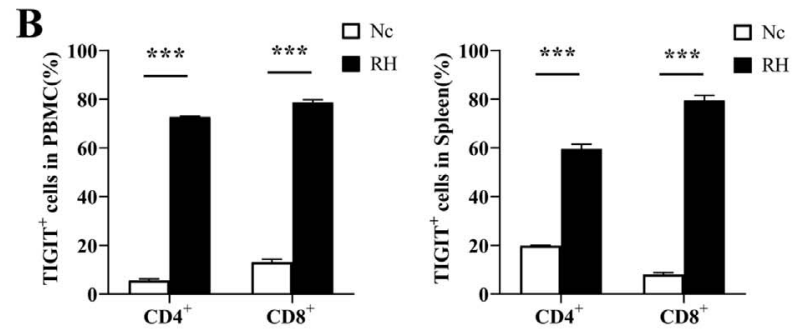

C
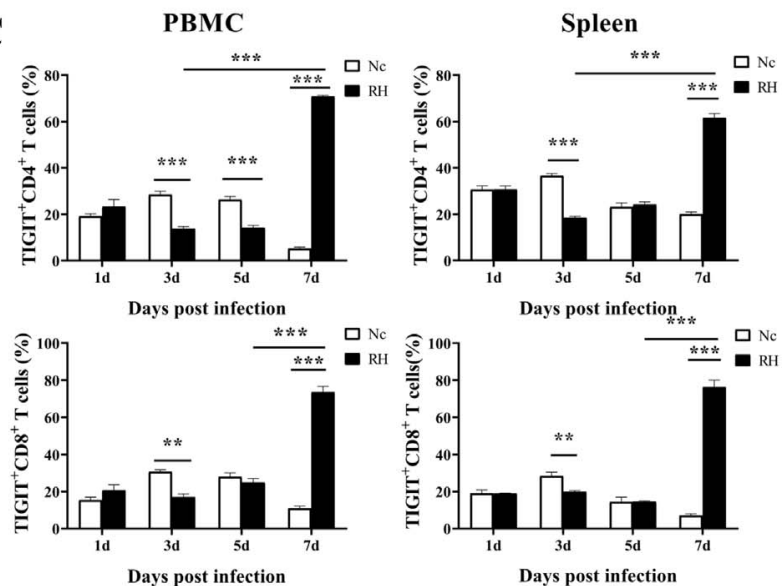

Figure 1. Changes in TIGIT expression on T cells in different tissues after $T$. gondii infection. (A) Proportions of TIGIT $^{+}$cells among $\mathrm{CD}^{+}{ }^{+}$and $\mathrm{CD}^{+}{ }^{+} \mathrm{T}$ cells in $T$. gondii-infected (RH) and normal mice (Nc) at 7 days after infection. (B) Results of statistical analysis of the percentage of TIGIT $^{+}$cells among $\mathrm{CD}^{+} \mathrm{T}$ and $\mathrm{CD} 8^{+} \mathrm{T}$ cells in $\mathrm{RH}$ and Nc mice at 7 days after infection. (C) Dynamic changes in the percentages of TIGIT $^{+}$in $\mathrm{T}$ cells at different time points. The results are representative of three independent experiments with five mice in each group per experiment, with data denoting means \pm SDs.

\section{Acute $T$. gondii infection selectively downregulated the expression of CD226 on T cells}

In contrast to that of TIGIT, even at 7 days after infection, the expression of CD226 on T cells was hardly affected by $T$. gondii infection $\left(\mathrm{CD} 226^{+} \mathrm{CD}^{+} \mathrm{T}\right.$ cells among PBMCs: $27.31 \% \pm$ $5.671 \%$ vs. $31.74 \% \pm 4.430 \%, p=0.48 ; \mathrm{CD} 226^{+} \mathrm{CD}^{+} \mathrm{T}$ cells among PBMCs: $93.28 \% \pm 3.949 \%$ vs. $86.42 \% \pm 6.86 \%$, $p=0.16$; $\mathrm{CD} 226^{+} \mathrm{CD} 4^{+} \mathrm{T}$ cells in the spleen: $32.53 \% \pm$ $3.249 \%$ vs. $28.80 \% \pm 3.73 \%, p=0.31 ; \mathrm{CD} 226^{+} \mathrm{CD}^{+} \mathrm{T}$ cells in the spleen: $84.03 \% \pm 0.725 \%$ vs. $83.31 \% \pm 2.275 \%$,

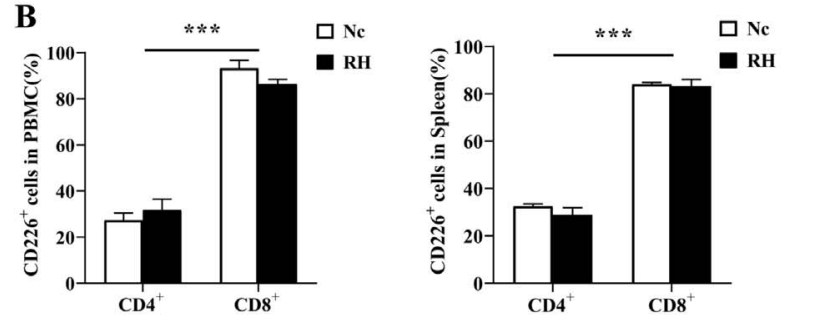

C
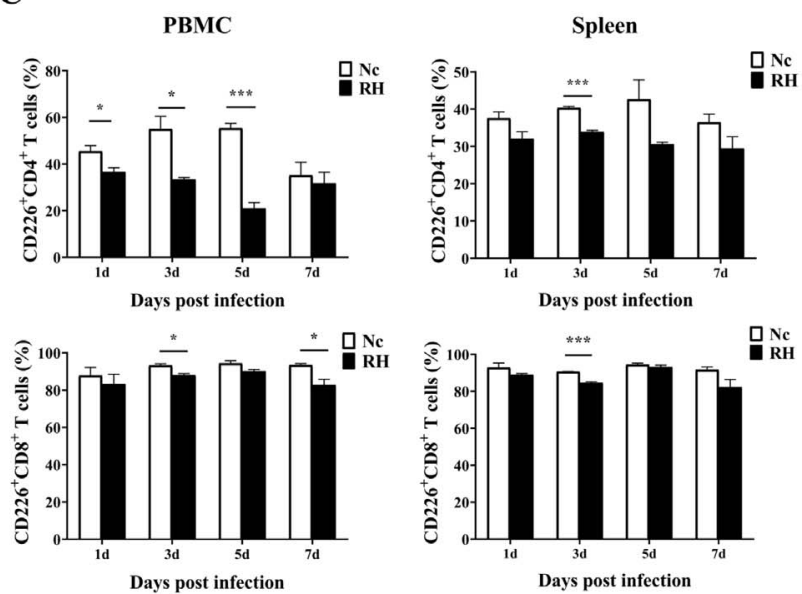

Figure 2. Changes in CD226 expression on T cells in different tissues after T. gondii infection. (A) Proportions of CD226 ${ }^{+}$cells among $\mathrm{CD} 4^{+} \mathrm{T}$ and $\mathrm{CD} 8^{+} \mathrm{T}$ cells in $T$. gondii-infected $(\mathrm{RH})$ and normal mice (Nc) at 7 days after infection. (B) Results of statistical analysis of the percentage of $\mathrm{CD} 226^{+}$cells among $\mathrm{CD} 4^{+} \mathrm{T}$ and $\mathrm{CD} 8^{+} \mathrm{T}$ in $\mathrm{RH}$ and $\mathrm{Nc}$ mice at 7 days after infection. (C) Dynamic changes in the percentages of $\mathrm{CD} 226^{+} \mathrm{T}$ cells at different time points. The results are representative of three independent experiments with five mice in each group per experiment, with data denoting means \pm SDs.

$p=0.77)$. CD226 appeared more frequently on the cell surface of $\mathrm{CD}^{+} \mathrm{T}$ cells than $\mathrm{CD} 4^{+} \mathrm{T}$ cells. However, on the third day after infection, the number of $\mathrm{CD} 226^{+} \mathrm{T}$ cells was lower in the infection group than that in the Nc group (Fig. 2).

\section{Acute $T$. gondii infection triggers an increase in $\mathrm{T}_{\mathrm{EM}}$ cells among $\mathrm{TIGIT}^{+} \mathrm{T}$ cells}

Memory $\mathrm{T}$ cells play a critical role in providing long-term immunity. Memory T cells are divided into four subsets based 
A
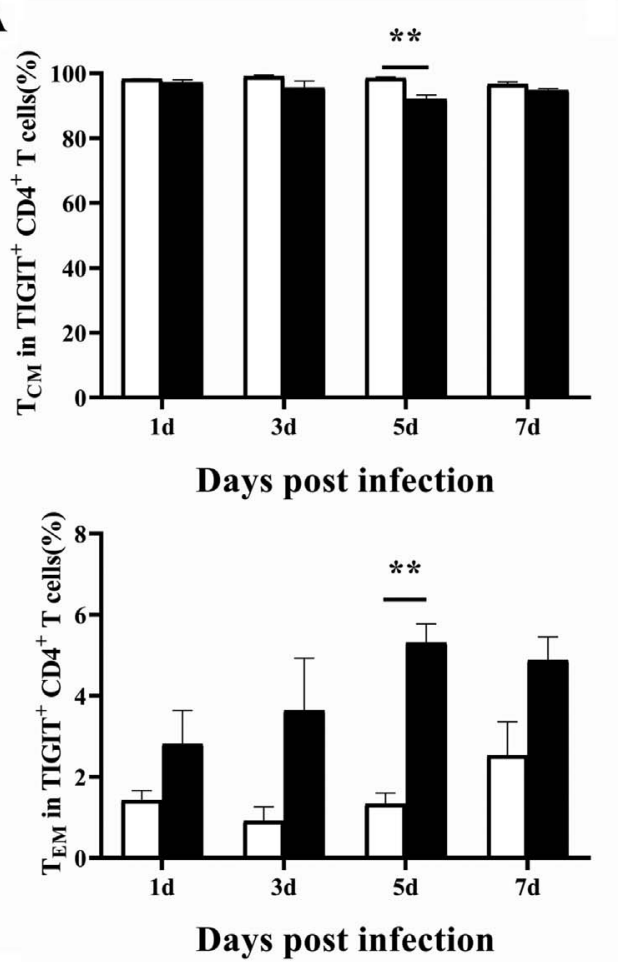

B
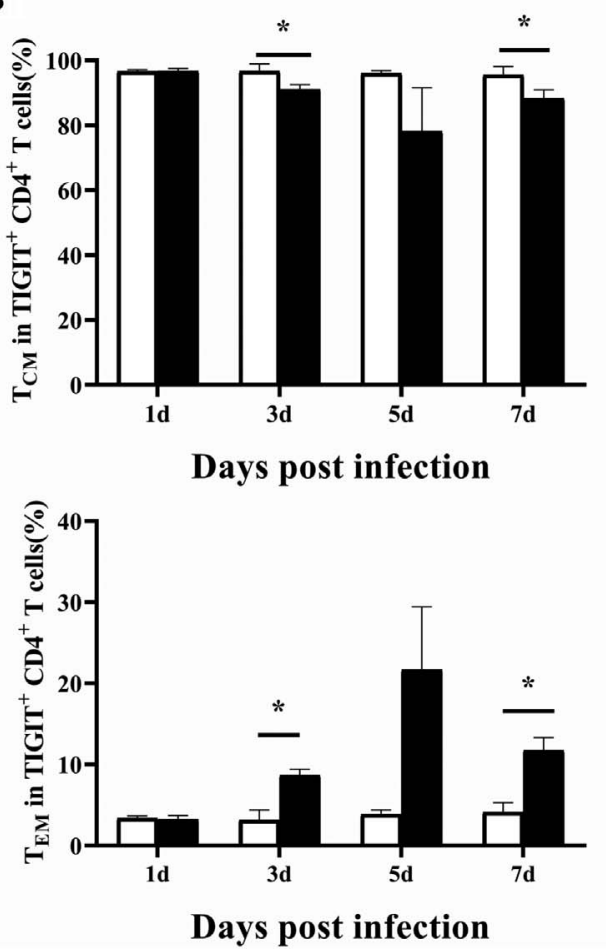

PBMC
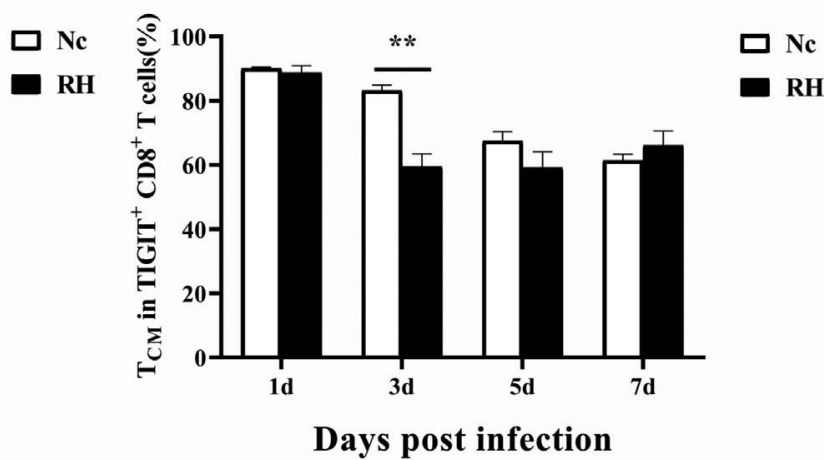

$\square \mathrm{Nc}$

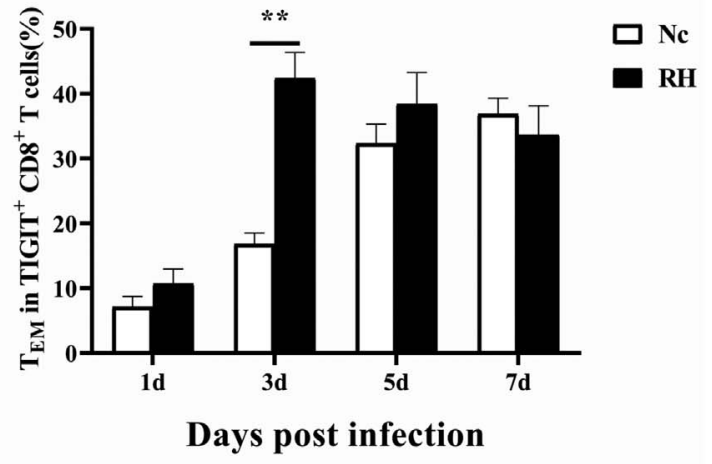

Spleen
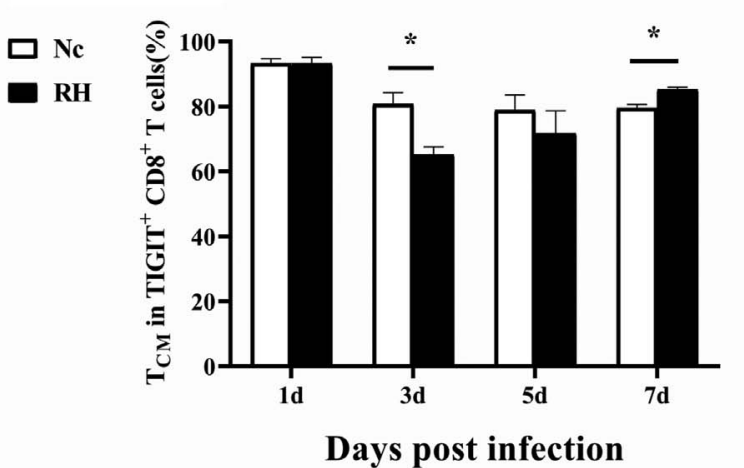

口 $\mathrm{Ne}$

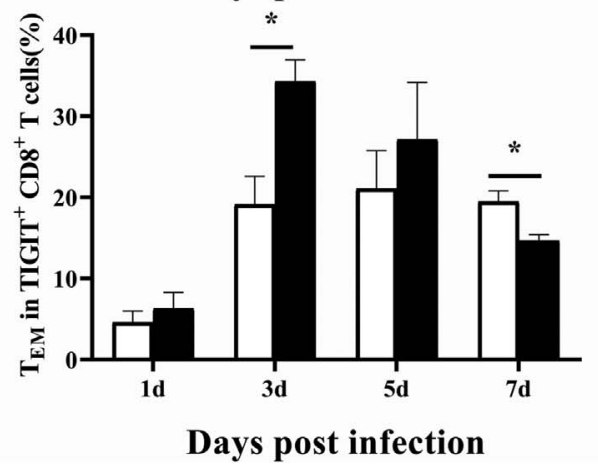

Figure 3. Relative contributions of memory $\mathrm{T}$ cell subsets of $\mathrm{TIGIT}^{+} \mathrm{T}$ cells after $T$. gondii infection. (A) Dynamic changes in memory $\mathrm{T}$ cell subsets of TIGIT $^{+} \mathrm{T}$ cell in PBMCs at different time points following RH infection. (B) Dynamic changes in memory $\mathrm{T}$ cell subsets of TIGIT $^{+} \mathrm{T}$ cells in the spleen at different time points following RH infection. The results are representative of three independent experiments with five mice in each group per experiment, with data denoting means \pm SDs.

on the expression of the cell surface markers CD44 and CD62L. We classified cells based on the expectation that central memory $\mathrm{T}$ cells are $\mathrm{CD} 44^{\mathrm{hi}} \mathrm{CD} 62 \mathrm{~L}^{\mathrm{hi}}$, effector memory cells are $\mathrm{CD} 44^{\text {hi }} \mathrm{CD} 62 \mathrm{~L}^{\mathrm{lo}}$, effector memory $\mathrm{T}$ cells are
$\mathrm{CD} 44^{\mathrm{lo}} \mathrm{CD} 62 \mathrm{~L}^{\mathrm{lo}}$, and naive memory cells are $\mathrm{CD} 44^{\mathrm{lo}} \mathrm{CD} 62 \mathrm{~L}^{\mathrm{hi}}$. Memory $\mathrm{T}$ cells subset analysis was performed on both TIGIT $^{+} \mathrm{CD}^{+}$and TIGIT $^{+} \mathrm{CD} 8^{+} \mathrm{T}$ cells. As shown in Figure 3, we found that $T_{C M}$ and $T_{E M}$ cells were the predominant subsets 
A
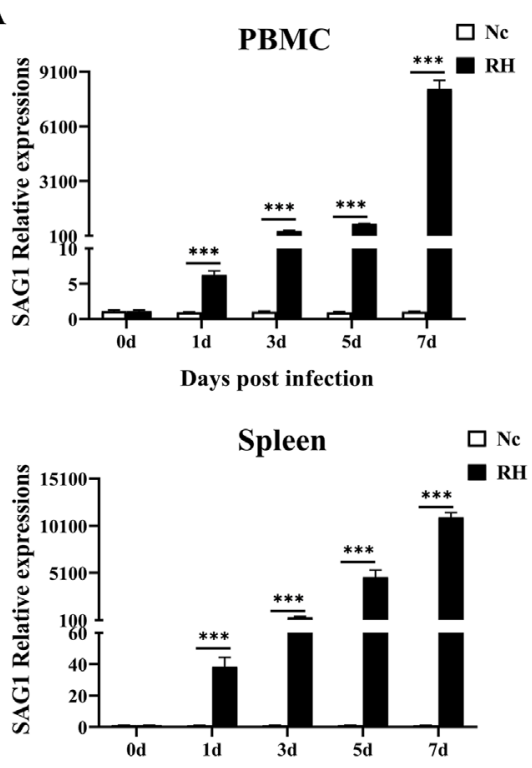

B

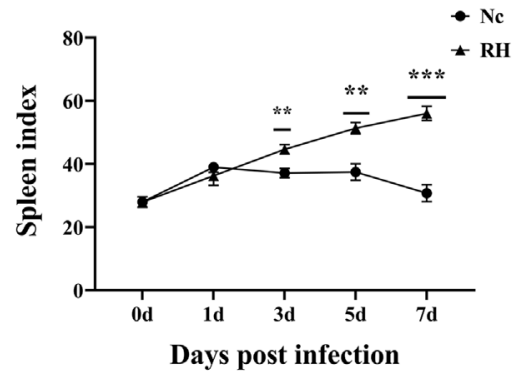

C

Day 0

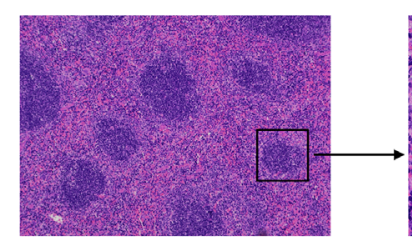

Day 1

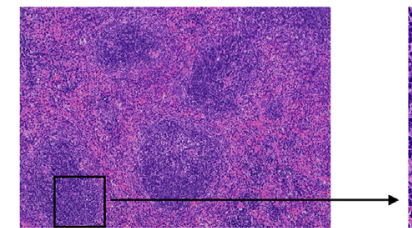

Day 3

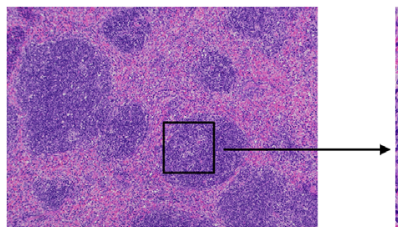

Day 5

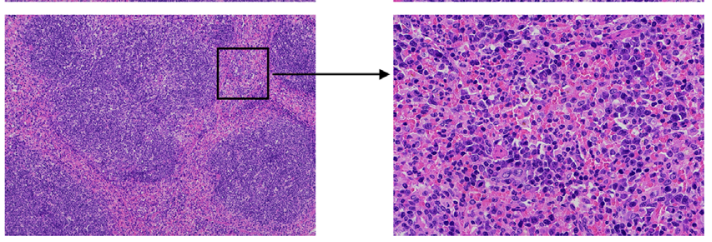

Day 7

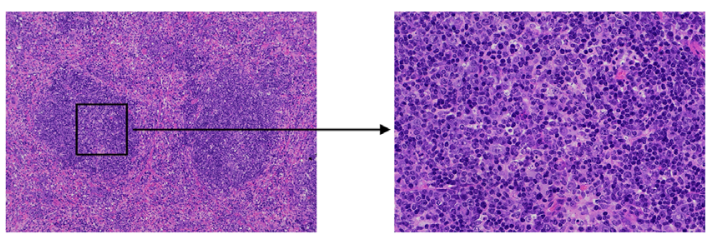

Figure 4. Dynamic pathological changes in the spleen during acute $T$. gondii infection. (A) Relative expression of TgSAG1 at $0,1,3,5$, and 7 days post infection in the PBMCs and spleen. (B) Spleen index values of the RH and Nc groups. The results are representative of three independent experiments with five mice per group per experiment; with data denoting means \pm SDs; (C) H\&E staining of spleen sections at different time points in the RH infection group. The original magnification was $100 \times$, and the corresponding images on the right were magnified at $400 \times$.

among T. gondii-specific TIGIT $^{+} \mathrm{T}$ cells. The phenotypic changes of TIGIT $^{+} \mathrm{T}$ cells in PBMCs were specific. The $\mathrm{T}_{\mathrm{CM}}$ subset was activated and transformed into $\mathrm{T}_{\mathrm{EM}}$ cells on the 3rd day after infection in TIGIT $^{+} \mathrm{CD} 8^{+} \mathrm{T}$ cells and on the 5 th day after infection in TIGIT $^{+} \mathrm{CD} 4^{+} \mathrm{T}$ cells. On the $3 \mathrm{rd}$ and 7th days post infection, the $\mathrm{T}_{\mathrm{CM}}$ subset of $T$. gondii-specific TIGIT $^{+} \mathrm{CD}^{+} \mathrm{T}$ cells in the spleen was activated and transformed into $\mathrm{T}_{\mathrm{EM}}$ cells. For the $\mathrm{TIGIT}^{+} \mathrm{CD} 8^{+} \mathrm{T}$ cells in the spleen, the $\mathrm{T}_{\mathrm{CM}}$ subset was activated and transformed into $\mathrm{T}_{\mathrm{EM}}$ cells on the 3rd day post infection, but the opposite happened on the 7 th day post infection (Fig. 3).

\section{Histopathological changes in the spleen were aggravated by an increasing $T$. gondii parasite load}

The relative expression of the $T$. gondii tachyzoite-specific gene SAG1 in PBMCs and spleen increased significantly from the first day post infection (Fig. 4A). Meanwhile, from the 3rd day after infection, the spleens of mice in the infected group rapidly enlarged, and the spleen index was significantly higher than in the control group (Fig. 4B). Through H\&E staining of spleen sections, we observed little change in the spleen on the first day post infection; the splenic sinus was intact, and the course of the splenic cord was normal. On the 3rd day post infection, infiltration of inflammatory cells, congestion in the middle of the splenic cord, and a compensatory increase in lymphocytes were observed. On the 7th day after infection, there was necrosis of spleen cells, complete destruction of the spleen structure, a decrease in lymphocytes, and a large number of tachyzoites and pseudocysts (Fig. 4C). The dynamic changes in TgSAG1 gene expression appeared consistent with the spleen pathology from days 3 to 7 post infection. These results showed that $T$. gondii tachyzoites quickly invaded the circulatory system and were then transported to various organs. Then tachyzoites further proliferated in the spleen by means of an immune escape mechanism and gradually destroyed spleen function.

\section{TIGIT and CD226 mRNA expression in PBMCs and spleen}

As shown in Figure 5, the relative expression level of TIGIT downregulated in the PBMCs and spleens of infected 

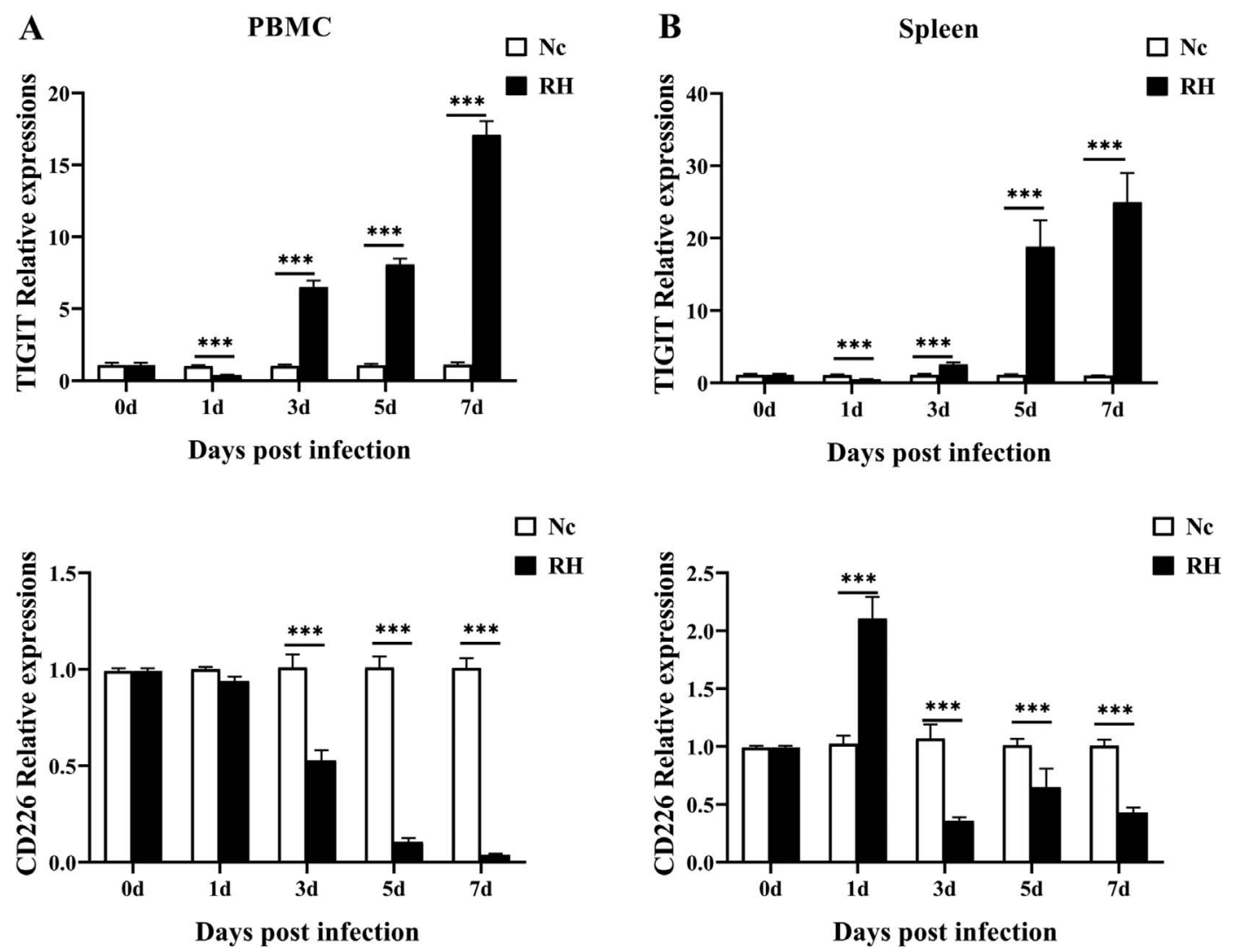

Figure 5. mRNA expression of TIGIT and CD226 in the PBMCs and spleens from mice infected with the T. gondii RH strain, as assessed by qRT-PCR. A: Data obtained from PBMCs. B: Data obtained from the spleen. Values are the means from triplicate measurements, with data denoting means \pm SDs; three independent experiments were performed with five mice per group. $* p<0.05, * * p<0.01$ and $* * * p<0.001$ (compared to the control).

mice on the first day after infection, while the expression of costimulatory receptor CD226 in the spleen of infected mice increased significantly. From the 3rd day after infection, the expression of TIGIT in PBMCs and spleens of the infected group was significantly higher than in the control group, and the down-regulation of CD226 was also observed at the same time point. These results showed that with an increasing T. gondii parasite load, the increased expression of TIGIT competitively suppressed the expression of CD226, resulting in a significant inhibition of cell-mediated immunity in mice infected with $T$. gondii.

\section{Discussion}

Previous studies have shown that TIGIT plays a pivotal inhibitory role in the immune system. However, research on TIGIT in the context of parasite infection is relatively scarce. Zhang et al. [24] found that the expression of TIGIT, CD3e, CD4 and CD8B was upregulated in the central liver tissue of patients with alveolar echinococcosis, and the expression of TIGIT was positively correlated with the expression of these factors. The same results were also observed in the mouse infection model. Further studies showed that blocking treatment with a TIGIT monoclonal antibody could significantly increase the content of CD4-Teffs ( $\mathrm{CD} 4^{+} \mathrm{Foxp}^{-} \mathrm{T}$ cells) and the ability of liver infiltrating $\mathrm{T}$ cells to secrete cytokines such as $\mathrm{IL}-2$, IFN- $\gamma$ and TNF- $\alpha$. Infection with Plasmodium yoelii could induce high expression of TIGIT on splenic $\mathrm{CD} 4^{+} \mathrm{T}$ cells in infected mice [21]. Zhang et al. [25] further demonstrated that the compensatory increase in TIGIT in P. berghei ANKAinfected mice was caused by blockade of the TIM-3-Gal-9 pathway with the TIM-3 ligand Galectin (Gal)-9 blocker $\alpha$-lactose, which may be one of the causes of death in mice. Zhang et al. [14] found that TIGIT can enhance the proliferation of $\mathrm{CD}^{+} \mathrm{T}$ cells in the spleen of mice infected with S. japonicum and then induce higher expression of IL-4 and lower expression of IFN- $\gamma$ to promote activation of the Th2 immune response. However, the expression pattern and function of TIGIT in the immune cells of mice infected with $T$. gondii were unknown.

In this study, we found for the first time that the expression of TIGIT on the surface of $\mathrm{CD} 4^{+}$and $\mathrm{CD} 8^{+} \mathrm{T}$ cells in the spleen and PBMCs decreased in the early stage but increased significantly in the late stage of acute $T$. gondii infection in a mouse model. On the 3rd day after acute infection, the expression of TIGIT and CD226 decreased in the PBMCs and spleens of the mice, suggesting that the immune system was activated and functional in the early stage of $T$. gondii infection, producing a large number of immune cells, enhancing immune activity, and eliminating free tachyzoites; however, at the same time, $T$. gondii formed pseudocysts to achieve immune escape. In the later stage of infection, $T$. gondii continuously disrupted 
the immune system, resulting in impaired immune activity. On the 7th day after infection, the expression of TIGIT in PBMCs and the spleen was significantly upregulated, eventually leading to immune failure and death. Studies have shown that the host T cell-mediated immune response plays an important role in the response to pathogen infection. Ackermann et al. [1] found that the number of $\mathrm{TIGIT}^{+} \mathrm{CD} 4^{+} \mathrm{T}$ cells in patients with acute hepatitis $\mathrm{C}$ virus (HCV) infection was significantly higher than in healthy controls, and TIGIT was highly expressed in all $\mathrm{CD} 4^{+} \mathrm{Tm}$ subsets (memory $\mathrm{T}$ cells). However, the mechanism of immune cell failure caused by pathogen infection, as well as whether this process is related to TIGIT, has not been well studied until now.

To further explore the effect of $T$. gondii infection on the phenotypic changes of TIGIT $^{+} \mathrm{T}$ cells, we analyzed the expression of CD44 and CD62L on TIGIT $^{+} \mathrm{T}$ cells by flow cytometry. The results showed that the TIGIT $^{+} \mathrm{T}$ cells of both the $\mathrm{Nc}$ and $\mathrm{RH}$ groups were mainly $\mathrm{T}_{\mathrm{CM}}$ cells, and the rest were $\mathrm{T}_{\mathrm{EM}}$ cells. $\mathrm{T}_{\mathrm{CM}}$ cells usually reside in $\mathrm{T}$ cell areas of secondary lymphoid organs and readily proliferate and differentiate into $\mathrm{T}_{\mathrm{EM}}$ cells, which are the predominant population elicited in response to antigenic stimulation during parasitic infection. These cells have little or no effector function, but persistent antigen stimulation maintains the effector function of memory $\mathrm{T}$ cells at a high level, which eventually leads to $\mathrm{T}$ cell exhaustion [18]. In this study, T. gondii-specific TIGIT $^{+} \mathrm{T}_{\mathrm{EM}}$ cells in the spleen increased on the 3rd and 7th days post infection, indicating that $\mathrm{T}_{\mathrm{CM}}$ cells were triggered to differentiate into $\mathrm{T}_{\mathrm{EM}}$ cells due to the increase in parasite load and antigen stimulation.

In addition, specific TgSAG1 expression in PBMCs and spleen increased significantly after $T$. gondii infection, and the expression of TIGIT was also considerably up-regulated, indicating that $T$. gondii infection can induce a large amount of expression of immunosuppressive receptors in the host, thus activating an immune escape mechanism and massive proliferation in the host, which eventually leads to destruction of the immune system and damage to immune function. Histopathological changes in the spleen were aggravated by an increasing T. gondii parasite load. By the 7th day after infection, the splenic structure of infected mice was completely destroyed, and the relative expression of TIGIT increased significantly, while $T$. gondii was still proliferating. These results are consistent with reports that $T$. gondii can cause host T cell exhaustion. However, the effect of TIGIT on the proliferation and cytokine secretion of $T$. gondii-specific $T$ cells is not clear, and whether $\mathrm{T}$ cell function can be restored after blocking the TIGIT pathway remains to be studied further.

\section{Conclusion}

Conclusively, our results indicated that acute $T$. gondii infection can increase the expression of TIGIT in host $\mathrm{T}$ cells and stimulate the transformation of TIGIT $^{+} \mathrm{T}_{\mathrm{CM}}$ cells into TIGIT $^{+} \mathrm{T}_{\mathrm{EM}}$ cells. Whether the increase in TIGIT expression induces exhaustion of host $\mathrm{T}$ cells during acute $T$. gondii infection, and whether TIGIT signaling blockade reverses the functional impairment of $\mathrm{T}$ cells needs to be studied further.

\section{Conflict of interest}

The authors declare that they have no conflict of interest.

Acknowledgements. The current work received support from the National Natural Science Foundation of China (No. 81702025), and the Science and Technology Planning Project of Henan Province (Nos. 182102310220 and 182102310431).

\section{References}

1. Ackermann C, Smits M, Woost R, Eberhard JM, Peine S, Kummer S, Marget M, Kuntzen T, Kwok WW, Lohse AW, Jacobs T, Boettler T, Schulze Zur Wiesch J. 2019. HCV-specific CD4+ T cells of patients with acute and chronic HCV infection display high expression of TIGIT and other co-inhibitory molecules. Scientific Reports, 9(1), 10624.

2. Berrocal Almanza LC, Muñoz M, Kühl AA, Kamradt T, Heimesaat MM, Liesenfeld O. 2013. Tim-3 is differently expressed in genetically susceptible $\mathrm{C} 57 \mathrm{BL} / 6$ and resistant $\mathrm{BALB} / \mathrm{c}$ mice during oral infection with Toxoplasma gondii. European Journal of Microbiology \& Immunology, 3(3), 211-221.

3. Bhadra R, Gigley JP, Weiss LM, Khan IA. 2011. Control of Toxoplasma reactivation by rescue of dysfunctional CD8+ Tcell response via PD-1-PDL-1 blockade. Proceedings of the National Academy of Sciences of the United States of America, 108(22), 9196-9201.

4. Boles KS, Vermi W, Facchetti F, Fuchs A, Wilson TJ, Diacovo TG, Cella M, Colonna M. 2009. A novel molecular interaction for the adhesion of follicular CD4 T cells to follicular DC. European Journal of Immunology, 39(3), 695-703.

5. Bottino C, Castriconi R, Pende D, Rivera P, Nanni M, Carnemolla B, Cantoni C, Grassi J, Marcenaro S, Reymond N, Vitale M, Moretta L, Lopez M, Moretta A. 2003. Identification of PVR (CD155) and Nectin-2 (CD112) as cell surface ligands for the human DNAM-1 (CD226) activating molecule. Journal of Experimental Medicine, 198(4), 557-567.

6. Casado JG, Pawelec G, Morgado S, Sanchez-Correa B, Delgado E, Gayoso I, Duran E, Solana R, Tarazona R. 2009. Expression of adhesion molecules and ligands for activating and costimulatory receptors involved in cell-mediated cytotoxicity in a large panel of human melanoma cell lines. Cancer Immunology, Immunotherapy, 58(9), 1517-1526.

7. Edwards JF, Dubey JP. 2013. Toxoplasma gondii abortion storm in sheep on a Texas farm and isolation of mouse virulent atypical genotype $T$. gondii from an aborted lamb from a chronically infected ewe. Veterinary Parasitology, 192(1-3), 129-136.

8. Flegr J, Prandota J, Sovickova M, Israili ZH. 2014. Toxoplasmosis-a global threat. Correlation of latent toxoplasmosis with specific disease burden in a set of 88 countries. PLoS One, 9(3), e90203.

9. Guirelli PM, Angeloni MB, Barbosa BF, Gomes AO, Castro AS, Franco PS, Silva RJ, Oliveira JG, Martins-Filho OA, Mineo JR, Ietta F, Ferro EA. 2015. Trophoblast-macrophage crosstalk on human extravillous under Toxoplasma gondii infection. Placenta, 36(10), 1106-1114.

10. Hwang S, Khan IA. 2015. CD8+ T cell immunity in an encephalitis model of Toxoplasma gondii infection. Seminars in Immunopathology, 37(3), 271-279.

11. Johnston RJ, Comps-Agrar L, Hackney J, Yu X, Huseni M, Yang Y, Park S, Javinal V, Chiu H, Irving B, Eaton DL, Grogan JL. 2014. The immunoreceptor TIGIT regulates antitumor and antiviral CD8(+) T cell effector function. Cancer Cell, 26(6), 923-937. 
12. Landrith TA, Harris TH, Wilson EH. 2015. Characteristics and critical function of CD8+ T cells in the Toxoplasma-infected brain. Seminars in Immunopathology, 37(3), 261-270.

13. Levin SD, Taft DW, Brandt CS, Bucher C, Howard ED, Chadwick EM, Johnston J, Hammond A, Bontadelli K, Ardourel D, Hebb L, Wolf A, Bukowski TR, Rixon MW, Kuijper JL, Ostrander CD, West JW, Bilsborough J, Fox B, Gao $\mathrm{Z}, \mathrm{Xu} \mathrm{W}$, Ramsdell F, Blazar BR, Lewis KE. 2011. Vstm3 is a member of the CD28 family and an important modulator of T-cell function. European Journal of Immunology, 41(4), 902-915.

14. Zhang L, Wang X, Qi Q, Dong L, Xu L, Pu Y, Wei C, Zhu J, Zhou S, Li Y, Liu F, Chen X, Su C. 2018. Study on role of TIGIT signal in Th1/Th2 balance in Schistosoma japonicuminfected mice. Chinese Journal of Schistosomiasis Control, 30(2), 136-139.

15. Lozano E, Dominguez-Villar M, Kuchroo V, Hafler DA. 2012. The TIGIT/CD226 axis regulates human T cell function. Journal of Immunology, 188(8), 3869-3875.

16. Montoya JG, Liesenfeld O. 2004. Toxoplasmosis. Lancet, 363 (9425), 1965-1976.

17. Ochiai E, Sa Q, Perkins S, Grigg ME, Suzuki Y. 2016. CD8(+) $\mathrm{T}$ cells remove cysts of Toxoplasma gondii from the brain mostly by recognizing epitopes commonly expressed by or cross-reactive between type II and type III strains of the parasite. Microbes and Infection, 18(7-8), 517-522.

18. Opata MM, Stephens R. 2013. Early decision: Effector and effector memory $\mathrm{T}$ cell differentiation in chronic infection. Current Immunology Reviews, 9(3), 190-206.
19. Schietinger A, Greenberg PD. 2014. Tolerance and exhaustion: defining mechanisms of T cell dysfunction. Trends in Immunology, 35(2), 51-60.

20. Vado-Solis IA, Suarez-Solis V, Jimenez-Delgadillo B, ZavalaVelazquez JE, Segura-Correa JC. 2013. Toxoplasma gondii presence in women with spontaneous abortion in Yucatan, Mexico. Journal for Parasitology, 99(2), 383-385.

21. Villegas-Mendez A, Inkson CA, Shaw TN, Strangward P, Couper KN. 2016. Long-Lived CD4+IFN- $\gamma+$ T Cells rather than shortlived CD4+IFN- $\gamma+$ IL-10+ T cells initiate rapid IL-10 production to suppress anamnestic $\mathrm{T}$ cell responses during secondary malaria infection. Journal of Immunology, 197(8), 3152-3164.

22. Xiao Y, Yin J, Jiang N, Xiang M, Hao L, Lu H, Sang H, Liu X, Xu H, Ankarklev J, Lindh J, Chen Q. 2010. Seroepidemiology of human Toxoplasma gondii infection in China. BMC Infectious Diseases, 10, 4.

23. Ye B, Liu X, Li X, Kong H, Tian L, Chen Y. 2015. T-cell exhaustion in chronic hepatitis B infection: current knowledge and clinical significance. Cell Death \& Disease, 6, e1694.

24. Zhang $\mathrm{C}$, Lin $\mathrm{R}$, Li Z, Yang S, Bi X, Wang H, Aini A, Zhang N, Abulizi A, Sun C, Li L, Zhao Z, Qin R, Li X, Li L, Aji T, Shao Y, Vuitton DA, Tian Z, Wen H. 2020. Immune exhaustion of T Cells in alveolar echinococcosis patients and its reversal by blocking checkpoint receptor TIGIT in a murine model. Hepatology, 71(4), 1297-1315.

25. Zhang Y, Jiang N, Zhang T, Chen R, Feng Y, Sang X, Yang N, Chen Q. 2019. Tim-3 signaling blockade with alpha-lactose induces compensatory TIGIT expression in Plasmodium berghei ANKA-infected mice. Parasites \& Vectors, 12(1), 534.

Cite this article as: Wang S, Li H, Zhang F, Jiao Y, Xie Q, Zhang Z \& Li X. 2021. Expression of TIGIT in splenic and circulatory T cells from mice acutely infected with Toxoplasma gondii. Parasite $\mathbf{2 8}, 13$.

- PARASTEE

An international open-access, peer-reviewed, online journal publishing high quality papers on all aspects of human and animal parasitology

Reviews, articles and short notes may be submitted. Fields include, but are not limited to: general, medical and veterinary parasitology; morphology, including ultrastructure; parasite systematics, including entomology, acarology, helminthology and protistology, and molecular analyses; molecular biology and biochemistry; immunology of parasitic diseases; host-parasite relationships; ecology and life history of parasites; epidemiology; therapeutics; new diagnostic tools.

All papers in Parasite are published in English. Manuscripts should have a broad interest and must not have been published or submitted elsewhere. No limit is imposed on the length of manuscripts.

Parasite (open-access) continues Parasite (print and online editions, 1994-2012) and Annales de Parasitologie Humaine et Comparée (1923-1993) and is the official journal of the Société Française de Parasitologie. 